\title{
Hubungan Pendidikan dan Pelatihan dengan Pelaksanaan Sistem Pemberian Pelayanan Keperawatan Profesional oleh Perawat Pelaksana di Ruang Rawat Inap RSUD Raden Mattaher Jambi
}

\author{
Indah Mawarti ${ }^{1}$, Fatma Sri Wahyuni ${ }^{2}$, Wawan Wahyudi ${ }^{3}$ \\ ${ }^{1}$ Mahasiswa S2 Keperawatan Universitas Andalas \\ ${ }^{2,3}$ Staf Pengajar Fakultas Keperawatan Universitas Andalas \\ Correspondence email: i.mawarti@yahoo.co.id
}

\begin{abstract}
Abstrak. Sistem Pemberian pelayanan keperawatan profesionla (SP2KP) merupakan komponen dari aplikasi nilai-nilai profesional dalam praktek keperawatan, manajemen dan pemberian asuhan keperawatan di unit ruang rawat rumah sakit dan perkembangan profesional diri. Tujuan dari penelitian ini adalah mengetahui adanya hubungan pendidikan dan pelatihan dengan pelaksanaan SP2KP oleh perawat pelaksana di ruang rawat inap RSUD Raden Mattaher Jambi. Adapun jenis penelitian yang dilakukan pada penelitian ini adalah penelitian kuantitatif dengan menggunakan desain penelitian analitik pendekatan cross sectional ( $\mathrm{n}=132$ perawat). Uji yang dipakai dalam penelitian ini uji Chy-Square. Pengambilan data dilakukan dengan kuesioner yang sudah diuji validitas dan reabilitasnya. Hasil penelitian hubungan pendidikan dan pelatihan dengan pelaksanaan sistem pemberian pelayanan keperawatan profesional oleh perawat pelaksana diruang Rawat Inap RSUD Raden Mattaher Jambi. Pendidikan yang mempunyai hubungan yang bermakna dengan pelaksanaan SP2KP (nilai $\mathrm{p}=0,010$ ). Saran peneliti kepada perawat pelaksana uuntuk meningkatkan pendidikan hal ini akan mempengaruhi skill dan pengetahuan perawat pelaksana dalam pelaksanaan SP2KP diruang rawat inap RSUD Raden Mattaher Jambi.
\end{abstract}

Kata kunci: Perawat Pelaksana; Pelaksanaan SP2KP; Ruang Rawat Inap

\begin{abstract}
Professional nursing service delivery system (SP2KP) is a component of the application of professional values in nursing practice, management and nursing care provision in hospital ward units and self-professional development. The purpose of this study was to determine the relationship between education and training with the implementation of SP2KP by implementing nurses in the inpatient room of Raden Mattaher Jambi Hospital. The type of research carried out in this study is a quantitative study using an analytic research design with cross sectional approach $(n=132$ nurses). The test used in this study is the Chy-Square test. Data is collected by using a questionnaire that has been tested for validity and reliability. The results of the study of the relationship between education and training with the implementation of a professional nursing service delivery system by implementing nurses in the Inpatient Room of Raden Mattaher Jambi Hospital. Education that has a significant relationship with the implementation of SP2KP ( $p$ value $=0.010)$. Researcher's suggestion to implementing nurses to improve education will affect the skills and knowledge of implementing nurses in the implementation of SP2KP in the inpatient room of Raden Mattaher Jambi Hospital.
\end{abstract}

Keywords: Implementing Nurse; SP2KP Implementation; Inpatient Room

\section{PENDAHULUAN}

Rumah sakit merupakan suatu bagian integral dari keseluruhan sistem pelayanan kesehatan yang menangani dan melayani pasien dengan berbagai jenis pelayanan. Era globalisasi yang terjadi saat ini para profesi kesehatan berupaya meningkatkan mutu pelayanan rumah sakit. Menurut Joint Commission on Accreditation of Health Care Organizations dalam Wasisto (1994), mutu pelayanan ialah dipenuhinya standar profesi dalam layanan dan terwujudnya hasil akhir sesuai dengan diharapkan. Hal ini didukung oleh Sitorus \& Panjaitan (2011), mutu pelayanan adalah suatu tingkat layanan memuaskan harapan pelanggan. Kedua pernyataan diatas disimpulkan bahwa mutu pelayanan adalah terpenuhnya standar profesi dalam layanan, terwujudnya hasil diharapkan, serta memuaskan harapan pelanggan. Bentuk kepuasaan pelanggan dapat dilihat dari capaian indikator mutu.

Indikator mutu dari pelayanan yang harus diperhatikan oleh rumah sakit antara lain: pemanfaatan tempat tidur, pemanfaatan tenaga, pemanfaatan penunjang medik, dan keuangan. Indikator pemanfaatan tempat tidur adalah melalui angka BOR (Bed Occupancy Rate), BTO (Bed Turn Over), ALOS (Average Lengthumah of Stay), TOI (Turn Over Interval) (Depkes.RI, 2005). Indikator-indikator mutu tersebut dapat dicapai oleh rumah sakit salah satunya adalah dengan peningkatan mutu pelayanan keperawatan.

Peningkatan indikator mutu pelayanan keperawatan salah satunya dapat dilakukan dengan penerapan standar pelayanan keperawatan profesional seperti penerapan sistem Pemberian Pelayanan Keperawatan Profesional (SP2KP). Menurut Kemenkes RI (2010) SP2KP adalah pengembangan dari Model Praktek Keperawatan Profesional (MPKP) dimana dalam SP2KP ini terjadi kerjasama profesional antara perawat primer (PP), dan perawat asosiet (PA). Berdasarkan pengertian SP2KP tersebut maka perawat dituntut untuk bekerja sama dalam meningkatkan pelaksanaan pelayanan keperawatan 
Pelaksanaan SP2KP merupakan aplikasi nilai-nilai profesional dalam praktik keperawatan, manajemen dan pemberian asuhan keperawatan di unit ruang rawat rumah sakit dan perkembangan profesional diri (Kemenkes RI, 2010). Banyak rumah sakit yang menerapkan model dan sistem SP2KP, Berdasarkan penelitian yang dilakukan oleh Wati, Ernawati \& Nurju'ah (2011) adanya hubungan tentang komponen pelaksanaan SP2KP Terkait dengan nilai- nilai profesional dengan pelaksanaan pemberian pelayanan keperawatan yaitu dengan nilai $(\mathrm{P}=0.003)$. Menurut hasil Penelitian Rantung, dkk (2013) mengatakan bahwa manajemen dan pemberian asuhan keperawatan lebih baik di ruang SP2KP dari pada non-SP2KP.

Pelaksanaan komponen SP2KP sangat penting untuk dilaksanakan terutama oleh perawat pelaksana yang memberikan asuhan keperawatan secara langsung kepada pasien. Perawat pelaksana sebagai pemberi jasa merupakan ujung tombak pelayanan di rumah sakit, karena perawat pelaksana berada 24 jam dalam memberikan asuhan keperawatan. Sehingga kinerja perawat menjadi sorotan baik oleh profesi lain maupun pasien atau keluarganya, jika hal tersebut tidak dilaksanakan akan berdampak terhadap menurunnya tingkat kepuasan pasien dalam pelayanan keperawatan. Tingkat kepuasan pasien merupakan salah satu indikator mutu pelayanan kesehatan (Nursalam, 2012).

Pelaksanaan SP2KP merupakan kinerja perawat dalam memberikan asuhan keperawatan yang dipengaruhi oleh beberapa faktor, yaitu: faktor kompetensi individu diantaranya pendidikan, pengalaman, pelatihan dan motivasi, faktor dukungan manajemen seperti kepemimpinan dan faktor dukungan organisasi diantaranya pengorganisasian, peralatan kerja dan syarat-syarat kerja (Simanjuntak, 2011).

Menurut Mangkunegara (2004), faktor yang mempengaruhi pelaksanaaan kinerja adalah faktor kemampuan (ability) dan faktor motivasi (motivation). Hal ini didukung oleh penelitian Hasmoko (2008), yang diperoleh hasil bahwa terdapat pengaruh antara motivasi dengan kinerja klinis perawat dalam melaksanakan Sistem Pengembangan Manajemen Kinerja Klinik (SMKK). Sehingga dapat disimpulkan bahwa semakin tinggi motivasi seseorang akan menghasilkan kinerja yang baik pula.

Rumah Sakit Umum Daerah (RSUD) Raden Mattaher Jambi merupakan rumah sakit type B pendidikan dengan kapasitas 365 tempat tidur dan jumlah tenaga keperawatan tahun 2013 sebanyak 487 orang. Bed Occupation Rate (BOR) tahun 2012 mencapai 82,5\% sedangkan pada tahun 2013 menurun menjadi $70,3 \%$. Data ini menunjukkan mutu pelayanan rumah sakit mengalami penurunan, meskipun masih diatas standar pelayanan minimal. Hal ini dapat disebabkan oleh sistem pelayanan keperawatan yang belum sesuai standar, sesuai dengan evaluasi penerapan SP2KP pada tahun 2013 hanya mencapai 62\% sedangkan evaluasi kepuasan pasien terhadap pelayanan keperawatan yang dilakukan dengan penyebaran kuesioner diperoleh hasil $72 \%$ responden merasa puas dengan pelayanan keperawatan yang diberikan oleh perawat. Data tersebut menunjukan bahwa persentase kapuasan pasien terhadap pelayanan keperawatan masih dibawah standar dimana menurut Standar Pelayanan Minimal (SPM) rumah sakit kepuasan pasien harus mencapai 90\% (Depkes RI, 2007)

Berdasarkan studi pendahuluan di RSUD Raden Mattaher Jambi, telah diterapkan SP2KP pada empat ruangan yaitu ruang bedah, pinang masak, mayang, dan Nurdin Hamzah. Sedangkan pada tahun 2012, SP2KP mulai diterapkan di seluruh ruangan. Perawat yang telah mengikuti pelatihan SP2KP sebanyak 5 orang, namun kegiatan sosialisasi SP2KP telah dilaksanakan di seluruh ruang perawatan dan pelatihan penunjang SP2KP dilakukan secara in hose training yang diikuti oleh perawat.

\section{METODE}

Penelitian ini merupakan penelitian kuantitatif dengan menggunakan desain penelitian analitik pendekatan metode cross sectional (potong lintang). Populasi dalam penelitian ini adalah seluruh perawat pelaksana yang betugas di Ruang Rawat Inap RSUD Raden Mattaher Jambi sebanyak 228 orang.

Menurut Nursalam (2012) dan Notoatmodjo (2010) apabila jumlah populasi < 10.000 dapat menggunakan formula sederhana dengan rumus sebagai berikut:

$$
\mathrm{n} \quad=\frac{N}{1+N\left(d^{2}\right)}
$$

Keterangan:

n : Jumlah sampel

$\mathrm{N} \quad$ : Jumlah Populasi

d : Tingkat signifikan5\% $\quad(0,05)($ dikutif dari

Zainudin M, 2002), $10 \%(0,10)$

Besarnya sampel dalam penelitian ini dengan populasi 198 adalah sebagai berikut:

$\mathrm{n}$

$$
\begin{aligned}
& =\frac{198}{1+198(0,05)^{2}} \\
& =\frac{198}{1,6} \\
& =132
\end{aligned}
$$

Jadi jumlah sampel dalam penelitian ini adalah sebanyak 132 perawat pelaksana.Pengambilan sampel dalam penelitian ini dilakukan secara Stratified proportional random sampling perawat pelaksana dibedakan atas masing-masing ruangan hal ini dilakukan untuk memberikan peluang yang sama kepada semua populasi untuk terpilih menjadi sampel. 
Indah Mawarti et al, Hubungan Pendidikan dan Pelatihan dengan Pelaksanaan Sistem Pemberian Pelayanan Keperawatan Profesional oleh Perawat Pelaksana di Ruang Rawat Inap RSUD Raden Mattaher Jambi

\section{HASIL DAN PEMBAHASAN}

Karakteristik pendidikan dan pelatihan Perawat Pelaksana di Ruang Rawat Inap RSUD Raden Mattaher Jambi

Tabel 1. Distribusi frekuensi Karakteristik perawat pelaksana berdasarkan pendikan dan pelatihan di RSUD Raden Mattaher Jambi

\begin{tabular}{lcc}
\hline \multicolumn{1}{c}{ Variabel } & F & \% \\
\hline Pendidikan & & \\
Vokasional & 111 & 84,1 \\
Professional & 21 & 15,9 \\
Total & 132 & 100 \\
Pelatihan & & \\
ada & 104 & 78,8 \\
tidak ada & 28 & 21,2 \\
Total & 132 & 100 \\
\hline
\end{tabular}

Berdasarkan pada tabel diatas didapatkan bahwa pada umumnya karakteristik perawat pelaksana di ruang rawat inap RSUD Raden Mattaher pendidikan mayoritas vokasional $84,1 \%$. Dan pendidikan profesional sebanyak $15,9 \%$.untuk perawat yang mengikuti pelatihan sebanyak $78,8 \%$ dan yang tidak sebanyak $21,2 \%$.

Tabel 2. Distribusi frekuensi Sistem Pemberian Pelayanan Keperawatan Profesional oleh perawat pelaksana di RSUD Raden Mattaher Jambi

\begin{tabular}{|c|c|c|}
\hline \multirow{2}{*}{$\begin{array}{c}\text { Variabel } \\
\text { PL.SP2KP oleh perawat }\end{array}$} & $\mathbf{f}$ & $\%$ \\
\hline & & \\
\hline Kurang baik & 41 & 31,1 \\
\hline Baik & 91 & 68,9 \\
\hline Total & 132 & 100 \\
\hline
\end{tabular}

Berdasarkan tabel menunjukkan bahwa lebih dari separuh pelaksanaan sistem pemberian pelayanan keperawatan profesional oleh perawat pelaksana baik yaitu $68,9 \%$

\section{Hubungan pendidikan, pelatihan, dengan pelaksanaan sistem pemberian pelayanan keperawatan profesional oleh perawat pelaksana Diruang Rawat Inap RSUD Raden Mattaher Jambi}

Tabel 3. Hubungan pendidikan dengan pelaksanaan sistem pemberian pelayanankeperawatan profesional oleh perawat pelaksana di ruang rawat inap RSUD Raden Mattaher Jambi

\begin{tabular}{lrllllll}
\hline Pddk & \multicolumn{3}{l}{$\begin{array}{l}\text { Pelaksanaan SP2KP } \\
\text { Kurang }\end{array}$} & \multicolumn{2}{l}{ Total } & paik \\
& \multicolumn{1}{l}{$\begin{array}{l}\text { Baik } \\
\text { f }\end{array}$} & $\%$ & \multicolumn{1}{l}{ f } & \multicolumn{1}{c}{$\%$} & \multicolumn{1}{l}{ F } & \% & \\
\hline DIII & 40 & 36,0 & 71 & 64,0 & 111 & 100 & \\
SI/Ners & 1 & 4,8 & 20 & 95,2 & 21 & 100 & 0.010 \\
Total & 41 & 31,1 & 91 & 68,9 & 132 & 100 & \\
\hline
\end{tabular}

Berdasarkan tabel persentase pelaksanaan sistem pemberian pelayanan keperawatan profesional yang baik lebih tinggi pada responden pendidikan Profesional dibandingkan dengan vokasional (95,2\% : 64,0\%). Secara statistik perbedaan tersebut bermakna $(\mathrm{p}<0,05)$

Tabel 4. Hubungan pelatihan dengan pelaksanaan sistem pemberian pelayanan keperawatan profesional oleh perawat pelaksana diruang rawat ianap RSUD Raden Mattaher Jambi

\begin{tabular}{|c|c|c|c|c|c|c|c|}
\hline \multirow{3}{*}{ Pelatihan } & \multicolumn{4}{|c|}{ Pelaksanaan SP2KP } & \multirow[t]{2}{*}{ Total } & & \multirow[t]{3}{*}{$\mathbf{P}$} \\
\hline & \multicolumn{2}{|c|}{$\begin{array}{l}\text { Kurang } \\
\text { baik }\end{array}$} & \multicolumn{2}{|c|}{ Baik } & & & \\
\hline & $\mathbf{f}$ & $\%$ & $\mathbf{f}$ & $\%$ & $\mathbf{F}$ & $\%$ & \\
\hline T.ada & 8 & 28,6 & 20 & 71,4 & 28 & 100 & \\
\hline Ada & 33 & 31,7 & 71 & 68,9 & 104 & 100 & 0,928 \\
\hline Total & 41 & 31,1 & 91 & 68,9 & 132 & 100 & \\
\hline
\end{tabular}

Berdasarkan tabel persentase pelaksanaan sistem pemberian pelayanan keperawatan profesional yang baik lebih tinggi pada responden pelatihan tidak ada dibandingkan dengan pelatihan ada $(71,4 \%: 68,9 \%)$. Secara statistik perbedaan tersebut tidak bermakna $(\mathrm{p}>0,05)$

\section{Pembahasan}

Pelaksanaan SP2KP oleh Perawat Pelaksana Diruang Rawat Inap RSUD Raden Mattaher Jambi Tahun 2014

Hasil analisis distribusi frekuensi menunjukkan sistem pemberian pelayanan keperawatan profesional diruang rawat inap RSUD Raden Mattaher Jambi sebagian besar $(68,9 \%)$ yang melaksanakan sistem pemberian pelayanan keperawatan profesional. Komponen pelaksanaan SP2KP terdiri dari: aplikasi nilai-nilai profesional dalam praktek keperawatan, manajemen dan pemberian asuhan keperawatan, dan pengembangan profesional diri (Kemenkes RI, 2010) adapun hasil penelitian yang didapat bahwa perawat pelaksana yang melakukan pelaksanaan aplikasi nilainilai profesional dalam praktek keperawatan baik di peroleh sebesar $(78,08 \%)$, sedangkan perawat pelaksana baik yang melakukan manajemen dan pemberian asuhan keperawatan sebesar $(67,54 \%)$. Dan hasil baik nilai pengembangan profesional diri perawat pelaksana sebesar $(54,26 \%)$.

Berdasarkan hasil penelitian oleh Wati, Ernawati, dan Nurju'ah (2011) menunjukan bahwa hasil distribusi frekuensi nilai-nilai profesional dalam peraktek keperawatan baik sebesar (48\%), manajemen dan pemberian asuhan keperawatan baik $(44 \%)$ dan pengembangan profesional diri perawat pelaksana baik $(52 \%)$ berdasarkan uji statistik menunjukkan tidak adanya hubungan yang bermakna manajemen asuhan keperawatan, pengembangan profesional diri terhadap pelaksanaan pemberian pelayanan keperawatan.

Analisis peneliti berdasarkan kuesioner yang didapatkan dari perawat pelaksana terkait komponen nilai-nilai profesional dalam praktek keperawatan didapatkan bahwa sebagian besar perawat pelaksana dalam melakukan tindakan bertanggung jawab dan tidak membedakan pasien, sedangkan rumah sakit dalam 
melakukan sosialisasi profesional tidak ada mempelajari perilaku mahasiswa baru yang bekerja sebesar $(53,3 \%)$. Menurut Jacox (1978) Sosialisasi profesional sangat diperlukan mahasiswa lulusan baru terkait proses internalisasi nilai-nilai keyakinan, menerima pengetahuan, keterampilan, sikap, keyakinan, normanorma, budaya, dan standar etik dalam keperawatan serta membuat hal ini sebagai dari " self image" dan perilaku yang dimiliki dirinya.

Manajemen dan pemberian asuhan keperawatan di ruang rawat inap RSUD Raden Mattaher sebagian besar $(99,2 \%)$ ruangan perawat pelaksana bekerja memakai metode tim, sebagian besar perawat pelaksana $(59,1 \%)$ dalam melakukan supervisi yang dilakukan oleh kepala ruangan jika perawat pelaksana melakukan kesalahan dalam pemberian asuhan keperawatan tidak adanya umpan balik .

Pengembangan profesional diri di ruang rawat inap RSUD Raden Mattaher sebagian besar (78\%) perawat pelaksana memuaskan pasien terhadap tindakan yang akan diberikan, sedangkan rumah sakit tempat perawat bekerja tidak memperhatikan peluang dengan cara meningkatkan kemampuan perawat sebesar (58,3\%). Menurut Ann Philbin (1996), pengembangan profesional di perlukan oleh rumah sakit terkait pengembangan tenaga perawat, melalui capacity bulding merupakan proses dalam mengembangkan dan menguatkan keterampilan, insting, kemampuan, proses dan sumber daya yang dimiliki agar individu, organisasi atau komunitas mampu bertahan beradaptasi di dunia yang berubah dan cepat (Kemenkes RI, 2010).

\section{Hubungan pendidikan perawat pelaksana dengan pelaksanaan sistem pemberian pelayanan keperawatan profesional di RSUD Raden Mattaher jambi}

Tingkat pendidikan merupakan satu-satunya faktor yang berhubungan dengan pelaksanaan sistem pemberian pelayanan keperawatan profesional oleh perawata pelaksana. Perawat pelaksana berdasarkan pendidikan juga menunjukkan bahwa tingkat pendidikan perawat pelaksana mayoritas adalah DIII keperawatan. Perawat pelaksana dengan pendidikan SI Keperawatan/ Ners masih tergolong sedikit.

Hal tersebut didukung oleh penelitian Arimurthy (2004) menunjukan bahwa pelaksanaan kerja perawat dipengaruhi oleh pendidikan. Menurut Siagian (2002), Pendidikan merupakan salah satu karakteristik data demografi yang penting dipertimbangkan karena dapat berpengaruh terhadap persepsi seseorang mengenai pelaksanaan sistem pemberian pelayanan keperawatan, Semakin tinggi pendidikan seseorang semakin besar keinginan untuk memanfaatkan pengetahuan dan keterampilan dalam melaksanakan sistem pemberian pelayanan keperawatan profesional.

Menurut Adrew E.Sikula dalam Mangkunegara (2004), tingkat pendidikan adalah suatu proses jangka panjang yang menggunakan prosedur sistematis yang terorganis, mempelajari pengetahuan konseptual dan teoritis untuk tujuan- tujuan umum. Menurut Notoatmojo (2005) pendidikan adalah proses penyampaian informasi kepada seseorang untuk mendapatkan perubahan perilaku. Hariandja (2002) menambah bahwa tingkat pendidikan seseorang karyawan dapat meningkatkan daya saing perusahaan dan memperbaiki kinerja perusahaan. Semakin tinggi pendidikan seseorang maka semakin besar keinginannya untuk memanfaatkan pengetahuan dan keterampilan yang dimiliki (Siagian 2012).

Menurut analisis peneliti Rumah Sakit Umum Daerah Raden Mattaher Jambi merupakan rumah sakit rujukan bagi rumah sakit kabupaten yang ada di propinsi jambi yang memiliki visi "Menjadikan rumah sakit pendidikan dan pusat rujukan melalui pelayanan prima, pendidikan yang bermutu, mandiri serta personal yang profesional". RSUD Raden Mattaher Jambi masih banyak perawat yang latar belakang pendidikan DIII Keperawatan, pada proses pengambilan data terhadap beberapa perawat pelaksana yang sedang melanjutkan pendidikan formalnya baik dengan biaya sendiri tanpa bantuan. Hal ini merupakan tindakan yang baik bagi peningkatan mutu pelayanan keperawatan.

Peneliti berpendapat bahwa pendidikan sangat mempengaruhi pelaksanan sistem pemberian pelayanan keperawatan profesional, semakin tinggi pendidikan seseorang semakit besar keingginan perawat untuk meningkatkan keterampilan yang dimilikinya. Menurut Delucia (2009), kompetensi yang dimiliki oleh seorang perawat ditentukan oleh latar belakang pendidikan, peran, jenis praktek. Jadi dapat disimpulkan tingkat pendidikan mempunyai pengaruh terhadap kompotensi yang dimiliki oleh perawat pelaksana. Kompetensi tersebut mempengaruhi pelaksaan yang dihasilkan oleh perawat pelaksana.

Berdasarkan hasil penelitian tentang pendidikan SI Keperawatan/Ners lebih baik karena perawat pelaksana di ruang rawat inap RSUD Raden mattaher Jambi selalu melaksanakan nilai-nilai profesional dalam praktek keperawatan terkait nilai etik dan legal dimana perawat pelaksana yang pendidikan profesional pada umumnya melakukan tindakan bertanggung jawab dan tidak membedakan pasien, perawat juga melakukan caring dengan cara memberi salam/ menyapa orang lain atau klien saat bertemu.

Manajemen dan pemberian asuhan keperawatan di ruang rawat inap RSUD Raden Mattaher perawat Profesional/ SI Ners melakukan komunikasi sesama tim dan ruangan tempat perawat pelaksana bekerja memakai metode Tim.

Perawat pelaksana vokasional/ DIII Kurang baik dalam pelaksanaan sistem pemberian pelayanan keperawatan profesional di karenakan dalam manajemen dan pemberian asuhan keperawatan di ruang rawat inap RSUD Raden Mattaher kepala ruangan dalam melakukan supervisi/bimbingan pekerjaan perawat tidak 
pernah dilakukan secara tiba-tiba sebesar $(59,5 \%)$, tidak adanya umpan balik jika melakukan kesalahan dalam pemberian asuhan keperawatan sebesar $(63,1 \%)$.

\section{Hubungan pelatihan perawat pelaksana dengan pelaksanaan sistem pemberian pelayanan keperawatan profesional di RSUD Raden Mattaher Jambi}

Penelitian menunjukkan bahwa tidak ada hubungan antara pelatihan dengan pelaksanaan sistem pemberian pelayanan keperawatan profesional oleh perawat pelaksana, dimana perawat yang tidak mengikuti pelatihan lebih baik pelaksanaan kerja. Menurut Marquis dan Huston (2010), pelatihan merupakan salah satu bagian terpenting dalam pengembangan staf.

Sulistyani \& Rosidah (2009) menyatakan pelatihan merupakan proses orientasi pada pegawai diberi informasi, pengetahuan tentang kepegawaian, organisasi dan harapan untuk mencapai pelaksanaan kinerja yang baik. Tujuan pelatihan adalah memperbaiki pelaksanaan kinerja pegawai sehingga keahlian pegawai meningkat sesuai dengan kemajuan teknologi.

Menurut analisis penelitian ini tidak sejalan dengan dengan teori, pelatihan kurang berdampak dalam meningkatkan pelaksanan pekerjaan. Program pelatihan bagi perawat sebaiknya berawal dari perawat yang lagi orientasi sehingga mendapatkan informasi dan pengetahuan tentang pelaksanan sistem pemberian pelayanan keperawatan profesional yang ada di RSUD Raden Mattaher Jambi untuk mencapai pelaksanaan yang baik.

Pelatihan tidak cukup menyebabkan perbaikan pelaksanan kinerja, adanya keinginan berubah dari pegawai yang mendapatkan pelatihan. Proses berubah sangat di pengaruhi oleh peran pemimpin dalam mendorong pegawai untuk berubah menjadi kearah yang lebih baik. Pegawai yang telah mendapatkan pelatihan perlu dievaluasi setelah pelatihan. pada hakikatnya pelatihan diprogramkan untuk meningkatkan pelaksanaan kinerja perawat dalam sistem pemberian pelayanan keperawatan profesional (Sulistyani \& Rosidah, 2009).

Manfaat pelatihan menurut Veithzal Rivai (2004) antara lain membantu karyawan mengatasi stres, tekanan, frustasi, konflik, menghilangkan rasa takut melaksanakan tugas baru, membantu karyawan dalam membuat keputusan dan pemecahan masalah yang lebih efektif, mendorong dan mencapai pengembangan diri dan rasa percaya diri, meningkatkan kepuasan pelaksanaan kerja dan pengakuan, sedangkan bagi perusahaan membantu mempersiapkan dan melaksanakan kebijakan perusahaan, menangani konflik sehingga terhindar dari stres dan tekanan kerja, menciptakan iklim yang baik untuk pertumbuhan, memperbaiki sumber daya manusia, pengetahuan kerja dan keahlian pada semua level perusahaan.
Menurut analisis peneliti bahwa pihak rumah sakit telah melaksanakan pelatihan-pelatihan terkait dengan SP2KP seperti pelatihan pasien safety, metode pemberian asuhan keperawatan, jenjang karir, BPGD dan lain-lain, sasaran pelatihan ini adalah perawat pelaksana. Pelatihan yang diikuti oleh perawat pelaksana hanya sebagian perawat yang dipilih oleh kepala ruangan yang mengutamakan perawat yang sunior, sedangkan perawat yang yunior belum banyak yang mengikuti pelatihan yang terkait dengan sistem pemberian pelayanan keperawatan profesional. Untuk itu pelatihan yang diadakan untuk perawat yunior sangat di utamakan untuk lebih meningkatkan pelaksanaan dalam bekerja. Pelatihan ini akan dipandang berbeda-beda oleh perawat pelaksana dengan latar belakang, umur, masa kerja serta pendidikan.

Berdasarkan hasil penelitian perawat pelaksana yang tidak mengikuti pelatihan baik dalam melaksanakan sistem pemberian pelayanan keperawatan karena perawat pelaksana sudah menjalankan nilai-nilai profesional dalam praktek keperawatan terkait dengan nilai etik dan legal, dimana perawat pelaksana yang tidak mengikuti pelatihan dalam melakukan tindakan keperawatan perawat bertanggung jawab, tidak membedakan pasien dan memberi salam/ menyapa orang lain/ klien saat bertemu dan ruangan tempat perawat pelaksana bekerja memakai metode tim. Hal ini sangat membantu perawat pelaksana yang tidak mengikuti pelatihan dalam melaksanakan SP2KP, karena dengan metode tim perawat yang tidak mengikuti bisa memperhatikan dan melihat perawat yang sudah mengikuti pelatihan.

Perawat pelaksana yang mengikuti pelatihan kurang baik dalam pelaksanaan sistem pemberian pelayanan keperawatan profesional sebanyak $(61,5 \%)$ karena untuk melakukan supervisi/bimbingan pekerjaan secara tiba-tiba tanpa pemberitahuan sebelumnya, tidak ada memberikan umpan balik jika perawat melakukan kesalahan dalam pemberian asuhan keperawatan sebesar $(62,5 \%)$.

\section{SIMPULAN}

Karakteristik Pendidikan perawat pelaksana mempunyai hubungan yang bermakna dengan pelaksanaan Sistem Pemberian Pelayanan Keperawatan Profesional. Pelatihan perawat pelaksana tidak mempunyai hubungan yang bermakna dengan pelaksanana Sistem Pemberian Pelayanan Keperawatan Profesional.

\section{Bagi manajemen Rumah sakit}

Berdasarkan Hasil Penelitian bahwa pelaksanaan sistem pemberian pelayanan keperawatan profesional oleh perawat pelaksan terhadap hubungan pendidikan dengan pelaksanaan SP2KP untuk itu perlunya bagi manajemen keperawatan memperhatikan pendidikan hal ini akan mempengaruhi skill dan pengetahuan perawat 
Indah Mawarti et al, Hubungan Pendidikan dan Pelatihan dengan Pelaksanaan Sistem Pemberian Pelayanan Keperawatan Profesional oleh Perawat Pelaksana di Ruang Rawat Inap RSUD Raden Mattaher Jambi

pelaksana dalam pelaksanaan SP2KP diruang rawat inap RSUD Raden Mattaher Jambi.

\section{Bagi perkembangan ilmu keperawatan}

Berdasarkan dari hasil penelitian menunjukkan pendidikan berhubungan dengan pelaksanaan sistem pemberian pelayanan keperawatan profesional hal ini dengan pendidikan perawat pelaksana bisa meningkatkan kemampuanya dan skill yang didapat dalam pendidikan dan akan berdampak baik terhadap pelaksanaan SP2KP.

\section{DAFTAR PUSTAKA}

Asmuji. (2012). Manjemen keperawatan konsep \& Aplikasi. Jakarta: perpustakaan nasional; katalok dalam terbitan (KDT)

Arimurty,S.P. (2004). Analisis kinerja perawat di instalasi rawat inap RSUD Wonogiri di kabupaten wonogiri. Fakultas kesehatan Masyarakat Universitas indonesia (tidak dipublikasikan)

Azwar, S. (2003). Sikap Manusia. Yogyakarta : Pustaka pelajar

Bidang Keperawatan RSUD Raden Mattaher. (2013). Data tenaga Keperawatan RSUD Raden Mattaher Tahun 2013.

Bugin. (2009). Metodologi penelitian kuantitatif komunikasi, ekonomi, dan kebijakan publik serta ilmu-ilmu sosialnya. Jakarta : penerbit kencana

Dahlan, M.S. (2008). Besar sampel dalam penelitian kedokteran dan kesehatan. Jakarta : CV. Agung seto

Dalani. (2010). Etika keperawatan. Jakarta : CV Trans info media

Delucia, P, R, Ott, T, E. (2009). Performance in nursing. Diunduh pada tanggal 09 juli 2014 pukul 09.00 pada

http://usil.academia.edu/patrickpalmieri/papers/16 4735/performance in Nursin

Depkes, RI. ( 2005). Indikator mutu pelayanan rumah sakit. Jakarta : Direktorat bina pelayanan medik spesialistik direktorat jenderal bina pelayanan medik departemen kesehatan

Depkes, RI. ( 2007). Draft Standar Pelayanan minimal Rumah Sakit.Jakarta : Direktorat bina pelayanan medik spesialistik direktorat jenderal bina pelayanan medik departemen kesehatan

Dessler,G.(2004). Manajemen sumber daya manusia.Ed.9.Jakarta: PT.Indeks

Dharma. (2011). Metodologi penelitian keperawatan panduan melaksanakan dan menerapkan hasil penelitian. Jakarta: Tran Info Media

Didinus, Indar \& Hamzah. (2013). Faktor-faktor yang berhubungan dengan kinerja perawat di ruang rawat ianp rumah sakit ibnu sina YBW -UMI. Jurna Bagian AKK FKM Universitas Hasanudin

Hariandja, M, T, E. (2002). Manajemen sumberdaya manusia. Jakarta: Grasindo
Hastono,S.P. ( 2007). Analisis data kesehatan. Depok. FKM-UI

Ilyas, Y. (2002). Kinerja:Teori penilaian dan penelitian . Depok: Badan penerbit Fakultas kesehatan Masyarakat Universitas Indonesia

Kemenkes, RI. (2010). Modul Pelatihan Sistem pemberian pelayanan keperawatan propesional (SP2KP). Bandung: Direktorat bina pelayanan keperawatan \& tehnisian medik direktur jendral bina upaya kesehatan.

Kurniadi, A. (2013). Manajemen Keperawatan dan Prospektifnya teori, konsep dan aplikasi.Jakarta : Penerbit Fakultas kedokteran Universitas Indonesia

Letvaks, S. (2008). Faktors Influencing work produktifity and intent to stay in nursing. Nursing economics. diundu pada tanggal 8 juli 2014 pada http:// findarticles.com/p/articles/mi_m0FSW/is 3 26/ai n 27507458/?tag=content; coll

Lusiani. (2006). Hubungan karakteristik individu dan sistim penghargaan dengan kinerja perawat menurut persepsi perawat pelaksana di RS Sumber Waras Jakarta. Fakultas Ilmu Keperawatan Universitas Indonesia (tidak dipublikasi)

Prasetyo \& Jannah. (2008). Metode penelitian kuantitatif. Jakarta : Raja grafindo persada

Rantung, Robin \& Hamel (2013). Perbedaan pendokumentasian asuhan keperawatan ruang SP2KP dan Non- SP2KP di IRNA A dan IRNA F RSUP PROF.DR.R.D.Kandou manado, Jurnal keperawatan, vol 1, No 1. Diunduh pada tanggal 14 Maret 2014 pukul 10.00 pada http://ejournal.unsrat.ac.id/index.php/jkp/article/vi ew/2241

Robbins,P.S. (2006). Perilaku organisasi. Edisi Bahasa indonesia.Ed.10. Jakarta: PT.Indeks kelompo Gramedia

Sastradijaya,H.J. (2004). Faktor-faktor yang berhubungan dengan kinerja perawat di ruang rawat inap RSUP Persahabatan Jakarta.. Fakultas Ilmu Keoperawatan Universitas Indonesia (tidak dipublikasi)

Siagian, S.P. (2002). Manajemen sumberdaya manusia. Jakarta : Bumi Aksara

Siagian.S.P. (2007). Manajemen Sumber daya manusia.Jakarta: Bumi Aksara

Siagian,S.P. (2012). Tiori Motivasi dan Aplikasinya.Jakarta : Rhineka Cipta.

Simanjuntak. (2011). Manajemen dan Evaluasi kinerja. Jakarta: lembaga penerbit Fakultas ekonomi universitas Indonesi

Sitorus \& Panjaitan (2011). Manajemen keperawatan : Manajemen Keperawatan di Ruang Rawat. Jakarta: Agung seto

Sopian, MM. (2008). Perilaku Organisasi.Yogyakarta.Andi 
Indah Mawarti et al, Hubungan Pendidikan dan Pelatihan dengan Pelaksanaan Sistem Pemberian Pelayanan Keperawatan Profesional oleh Perawat Pelaksana di Ruang Rawat Inap RSUD Raden Mattaher Jambi

Suarly\& Bahtiar. (2009). Manajemen keperawatan dengan pendekatan praktik.Jakarta: Erlangga

Sulistyani, A.T \& Rosidah. (2009). Manajemen Sumber daya manusia : konsep teori dan pengembangan dalam konteks organisasi public.Yogyakarta: Graha Ilmu

Sumijatun. (2009). Membudayakan etika dalam praktek keperawatan. Jakarta : salemba medika

Suyanto. (2009). Mengenal kepemimpinan dan manajemen keperawatan di rumah sakit.Yokyakarta: Mitra cendika

Mangku Negara,A.P. (2004). Manajemen sumber daya manusia perusahaan. Bandung: PT. Renaja Rosdakarya.

Marquis \& Huston. (2010). Kepemimpinan dan manajemen Keperawatan Teori dan Aplikasi. Edisi ke-4 penerbit buku kedokteran

Manurung, S.(2011). Keperawatan Profesional. Jakarta : Trans Info Media

Muninjaya. (2012). Manajemen kesehatan. Jakarta : Penerbit buku kedokteran EGC

Muzaputra, G. (2008). Hubungan karakteristik individu dan faktor organisasi dengan kinerja perawat di RSUD Langsa NAD. fakultas keperawatan universitas indonesia 9tidak dipublikasi)

Notoatmojo, S. (2005). Promosi kesehatan teori dan aplikasi. Jakarta: Rineka cipta

Notoatmojo, S. (2010). Metodologi penelitian kesehatan. Jakarta: Rineka cipta

Nursalam. (2011). Konsep dan penerapan metodelogi penelitian ilmu keperawatan. Jakarta: Selemba Medika.

Nursalam. (2012). Manajemen Keperawatan Aplikasi dalam praktek keperawatan Profesional.Jakarta : Salemba Medika

UU Republik Indonesia Nomor 44 tahun 2009 tentang rumah sakit

Veithzal Rivai. (2004). Manajemen sumber daya manusia untuk perusahaan dari teori ke praktek. Jakarta : Penerbit PT.Raja Grafindo Persada

Wati, Ernawaty \& Nurju'ah. (2011). Analisa pelaksanaan pemberian pelayanan keperawatan diruang Murai I dan Murai II RSUD Arifin Achmad Propinsi riau , jurnal Ners Indonesia, vol 1, No.2 Diunduh pada tanggal 14 Maret 2014 pukul $10.00 \quad$ pada http://ejournal.unri.ac.id/index.php/JNI/article/do wnload/635/628 